\title{
MINING LEFTOVERS: Making Futures on the Margins of Capitalism
}

\section{PABLO JARAMILLO \\ Universidad de los Andes, Bogotá}

(iD) https://orcid.org/0000-0002-8960-3275

During a meeting held in the governor's office of the Department of Caldas, in the central Colombian Andes, a group of officers, geologists, and anthropologists, including myself, debated the ongoing mining conflicts in the region. The agenda included a feud between small-scale miners and a Canadian mining company, as well as the illicit extraction of alluvial gold from the Cauca River. The paradox, pointed out by the secretary of government, was that "small-scale miners don't have a future." By that, he meant that they do not fall into the country's grand scheme of resource governance, recognized in the Mining Code (2001) and in the most recent resource policies. ${ }^{1}$ But he also meant that miners lacked a sense of saving, planning, and thinking ahead. "All the money they make," he added, "gets spent on partying, women, and booze."

Interestingly, small-scale miners think that the ones who lack a sense of future are the large-scale mining companies. Mario, a young self-employed man who operates a mine without an official title, stated that "the town has been here for centuries; the mining company will exhaust all the deposits in a decade." We should understand his comments in the context of small-scale miners' affective relationship with gold, in which the metal is seen to "reproduce itself" in the mountain. This is achieved through the miners' entanglement with technologies, 
minerals, and the activation of potentialities in the materials that surround the extraction of the precious metal. Corporate and governmental actors ignore the intimate and affective relationships with the geological substances involved in gold extraction, which renders the everyday practices of future-making illegible. In contrast, small-scale miners constantly create a sense of future through an engagement with what looks like waste: mud, sand, rubble, and toxic gases resulting from the extractive process. I will generically call these substances leftovers, because they point to an excess and are potentiality contained in the matter remaining after the gold is extracted. Small-scale miners are at the center of global financial capitalism and deploy capitalist ways of organizing labor and property. But by engaging with remnants, they achieve a sense of vital production and reproduction despite the vagaries of life, the cycles of extractive and financial capitalism, and local violence. Leftovers thus point to the way actors under current economic regimes are at once marginalized and dominant, victims and agents, depending on the temporal and spatial scale of production.

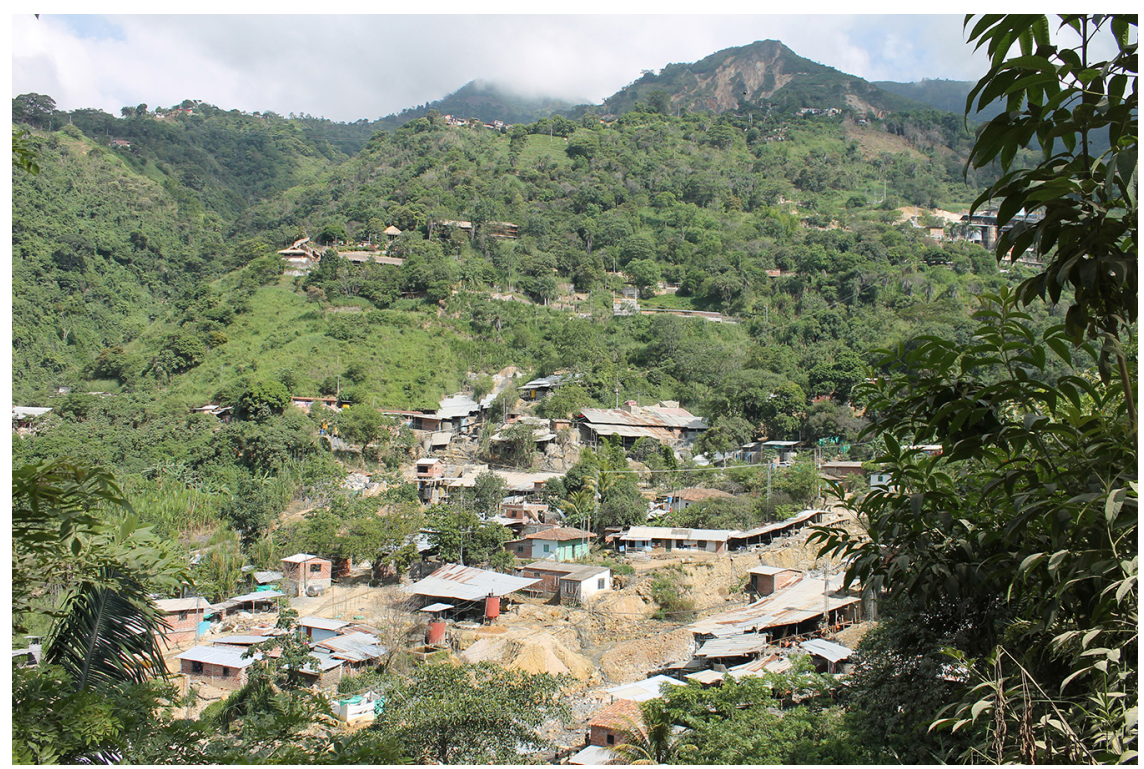

Figure 1. The mountain and Marmato. Photo by Pablo Jaramillo.

I understand these engagements with leftovers as part of a subsistence strategy of small-scale mining communities in their experience of marginalization and violence at several scales. In contemporary Colombia, global processes intermingle with local violence fueled by valuable resources such as cocaine, gold, and coltan. 
On the one hand, in the years before and after the 2008 global financial crisis, the Latin America gold boom accounted for 50 percent of the world's mineral exploration (Bury and Bebbington 2013). Mineral resources became a hedge in an environment of financial risk, skyrocketing gold prices to US $\$ 1,875$ per ounce in 2011. ${ }^{2}$ Gold mining and trading companies responded by aggressively attracting investment. Colombia, in turn, responded by progressively opening itself to direct foreign investment and criminalizing miners that did not fit the large-scale mining model. High prices also fueled the long-standing armed conflict, which has transformed swiftly over the past ten years: it went from a confrontation between large, organized guerrillas, structured paramilitaries, and the Colombian army to the atomization of belligerent groups and criminal gangs. This transformation has meant a change in the control over profitable commodities.

Despite the risks, small-scale and traditional mining communities still see in gold a promised, if elusive, future, even when they have to deal with local mafias and their own criminalization by the national government. In this vein, the inhabitants of Marmato manipulate a wide range of things that might seem valueless to an outsider but that from the inside, hold the promise of extending miners' present. To make a living, small-scale miners use, circulate, and recirculate every single element that potentially contains gold. No "waste" exists in miners' eyes, only leftovers, geological objects with potential agency. Amid the risks caused by insecurity and crisis, small-scale miners create a sense of future through their affective (and always material) engagement with the leftovers of gold mining, feeding their own lives in the margins of global financial capitalism. From the point of view of everyday engagements with leftovers, these multiple processes constitute practices of future-making, entailing temporal affects involving a sense of pace, rhythm, duration, and future. The miners' relationship with tailings, rubble, and toxic substances constantly coming from the mines and minerals prove central to notions of anticipation and reproduction. The affective relationship between mining remnants and miners is contradictory but generative, heavy with both fears and ambitions of a prosperous future.

In theoretical terms, leftovers point to affects emerging from human-nonhuman collaborations, perdurances, and practices of future-making in the context of capitalist marginalization. Precarious lives in mining towns ultimately survive on the gold that sustains risky investments, but also through material forms that remain dangerously and vitally dormant in their surroundings. In that way, leftovers also point to heterogeneous ways of experiencing and conceptualizing valu- 
able objects that simultaneously constitute resources, by-products, reserves, and waste.

The town of Marmato, in the central Colombian Andes, offers a good case in point, as an intimate and affective relationship with minerals fosters local relations and political openings that oppose transnational corporations. This article has resulted from ethnographic fieldwork conducted between 2016 and 2017 in the border region between the Department of Caldas and Antioquia, Manizales (Caldas's capital city), and Bogotá (Colombia's capital city). I conducted interviews with small-scale miners, local leaders, governmental officers, and local residents. I also spent a considerable amount of time in and around mines and mills, carrying out participant observation on the process of gold extraction. In the capital cities, I conducted interviews with government officers and private-sector representatives, and I also attended public fora on mining issues.

\section{DWELLING AND WORKING IN THE MARGINS OF CAPITALISM}

The paradox at the core of the future of small-scale miners is that it is illegible from the point of view of bureaucrats and corporate officers. Back in the meeting room of the governor of the department of Caldas, there were about half a dozen rocks of pyrite, also called fool's gold or tourist gold by local miners. Miners offered me many of these rocks as presents, but they said that they did not contain gold and were therefore considered waste in the extractive processes. The rocks in the governor's meeting room are most likely leftovers that have become gifts. All the officers working in the governance of gold or mining territories that I met during my fieldwork seemed to decorate their offices with such stones. So, what are these pyrite rocks doing there? As gifts, they already form part of a formula by which small-scale miners attempt to build their presence in governmental offices that, in many cases, criminalize them. Beyond leftovers given as gifts, there are multiple engagements between a variety of leftovers (gases, muds, tailings, and rubble) and miners that create a sense of an enduring and resilient life.

Marmato is one of the world's oldest gold-mining sites. It has gone through recurrent cycles of boom and bust, producing different extractive regimes, all of which have left layer upon layer of marginalization. Today, Marmato's nine thousand inhabitants also live on the verge of a looming boom that will erase the town for good. In the early 2000s, a large-scale Canadian mining company acquired all mining titles, including some that overlap with the historic center. To the company, the site is destined to become a large open pit mine, meaning the total elimination of Marmato's buildings. Dwellers and the many people who still work in the 
shafts fiercely oppose this future. Far from being passive victims of destruction, small-scale miners challenge temporal dispossession, "or the inability to plan, predict, or build futures in an incremental way" (Smith 2011, 17), by retrieving gold in every piece of matter available. Nowhere does this become more visible than in the engagement with leftovers in artisanal and small-scale mining activities.

Entanglements between resource extraction and the past are a common concern in recent literature about ruins and ecological degradation (Ferry and Limbert 2008; D’Angelo and Pijpers 2018). Recent anthropological research on small-scale mining and extractive industries has emphasized the importance of considering the way in which mineral extraction entails not only changes to landscapes and wealth but also complete cosmological transformations (High 2017, 22). Mines, even after closure, remain an important link between past, present, and future for local communities (Halvaksz 2008; Beckett and Keeling 2019). Likewise, research on contemporary capitalist enterprises (Richard and Rudnyckyj 2009; Blanco, Arce, and Fisher 2015; Weszkalnys 2016) has highlighted the importance of affect in the production of resources, commodities, and labor. Thinking about affect also helps overcome notions of the economy as guided solely by rational means.

Temporality and affect entail a dynamic and processual perspective on the relationship between humans and natural resources. Such an approach encourages us to consider the agency of nonhuman entities in the analysis of extractive and financial capitalism. Studies on precariousness and ruination show the ways in which capitalism acts through a dialectic of production and the destruction of infrastructures (Stoler 2008; Gordillo 2014; Millar 2014). As more objects, subjects, and relations repopulate the economy, the concept of work expands to include nonhuman entities. Sarah Besky (2014), for example, analyzes Darjeeling plantations as systems in which terroir works to create a particular type of tea, rearticulating forms of colonial labor. In Besky's analysis, nonhumans work to obscure human labor. Similarly, Mazen Labban (2014) has developed a model in which recycled metals and bacteria used in the process of mineral extraction create novel forms of capital.

In brief, while many analyses have concentrated on the way large-scale mining companies attempt to frame humans, nonhumans, and their futures in ways instrumental to their operations (Kneas 2016; Luning 2018), I am interested mostly in the ways local communities engage with nonhuman entities in practices of future-making and resilience, in the face of the imminent annihilation of their ways of life. Similarly, while nonhuman forms of work have emerged as promising analytics, studies tend to emphasize the way the work of animals, plants, and bacteria 
become articulated in ever-growing circuits of capital, but not the ways in which they challenge them.

I want to point to other alternatives. As explained by Sebastián Ureta (2016), mining waste points to the importance of a caring relationship between humans and nonhumans in extractive activities. Ethnographic studies on small-scale mining processes and temporalities show similar results. For example, Nancy Lee Peluso's (2018) analysis of the territorializing practices of small-scale miners has effectively countered the notion that resource territories are solely constructed from above, that is, from state and corporate perspectives. In another example, small-scale gold miners in west Africa manage to "make time" amid rapid change in extraction techniques, migrating workforces or the depletion of miners (Lanzano 2018). And as part of small-scale gold mining and social conflict in the Amazon project (www.gomiam.org), many anthropologists have demonstrated the importance of a temporal dimension to understanding why mining conflicts do not turn violent (Salman and de Theije 2017), as well as the kind of innovations that help miners achieve sustainable production without the kind of solutions suggested by large-scale companies (Massaro and de Theije 2018). James H. Smith's (2011) studies on Congolese coltan have shown that people effectively respond to temporal dispossession by socializing the coltan that is otherwise a cause of death and displacement. For instance, people create coltan-infused beverages that make them invulnerable or even bulletproof. By, among other things, treating coltan as food, Congolese people reverse the ore's violence and manage to conceptualize the metal as socially productive. Closer to this latter perspective, I aim to show that engagements with leftovers — wasted matter with potential agency — prove crucial to understanding future-making among small-scale miners. In this sense, the work of and around leftovers shows that human and nonhuman engagements recast our understanding of small-scale miners' capacity to stay alive amid threats, while simultaneously remaining part of capitalist cycles of production and consumption.

Anna Lowenhaupt Tsing's (2015) work on mushroom pickers, scientists, and traders has offered a framework for understanding life growing and reproducing on the edges of capitalism. The most relevant aspect of Tsing's work for the current analysis is the insight that life in the ruins of capitalism grows at different "rates of being" (see also Gilbert 2007) in a polyphony of life. Thus, human and nonhuman engagement allows for a more comprehensive understanding of survival in the context of harm inflicted by corporations. It reveals the everyday strategies that counter the politics of resignation in contemporary capitalism (Benson and 
Kirsch 2010). In the context of ruination and ecological degradation, I argue that human and nonhuman forms of life grow and perdure.

This does not mean that we should understand the survival strategies of small-scale miners as radically opposed to capitalism. Investors in global financial centers hedge their risks through the financialization of gold coming from marginalized regions in Colombia and the world. Thus, small-scale gold extraction always remains immersed in global economic logics. Recent works on modern time (Bear 2014) and potentiality (Weszkalnys 2015) in capitalism have shown how, through speculation, economies incorporate pause and delay, which were formerly deemed as largely detrimental to growth but are, in fact, central to practices of value making that affect the most vulnerable populations and landscapes. Local communities live in equally heterogeneous times and potentialities (Bear 2014). These studies tend to emphasize the way potentiality is instrumental to resource making and capital accumulation. Corporations activate or deactivate potentialities to make profit or create opportunities. But, as I will show in the following sections, potentialities in leftovers can also be important in creating opportunities for survival in the long-standing precariousness of the global South (Millar 2014). Human and nonhuman engagements surrounding Marmato's mining conflict account for alternative ways of reckoning with their crisis-ridden present and uncertain future.

\section{SOCIOTECHNICAL TRANSITIONS}

I came across people living amid mining fumes, rubble, mud, and sand while trying to understand the politics of a conflict over one of the richest gold deposits in the world. Marmato is a town located in a mountain crisscrossed by gold veins, mined since pre-Columbian times and, later, through several booms and busts (Gärtner 2005; González Colonia 2017). The town forms part of a broader constellation of mining towns (Remedios, Buriticá, and El Bagre to the north, and Suárez and Buenos Aires, to the south) undergoing deep transformations as migrants, the urban and rural poor, gangs, ex-combatants of Colombia's long-standing conflict, and transnational corporations strive to extract and transact gold. Successive waves of extraction and abandonment have created a regime of production in which the higher part of the mountain has become occupied by small-scale miners, while the lower part is worked by medium-sized companies (recently acquired by a large-scale Canadian company striving for full control of the mineral deposit). At the top, there are Indigenous people, Afro-Colombian descendants of slaves, and mestizo populations that have remained in the town through an entangled network of economic, political, and kinship relations. Some people have recently arrived in 
the town with dreams of changing their luck, and others who work as miners but live in nearby towns commute daily.

In 2006, as the financial crisis of 2008 was approaching, a Canadian transnational corporation, Gran Colombia Gold, bought 80 percent of the mining titles in the higher part of the mountain. The town then filled with drilling equipment and consultants working for the relocation of the historic center, which fueled financial speculation and local stories about the possible futures of Marmato. The company wanted to conduct large-scale mining operations and evict local residents. For some time, they proposed an open-cut mine, which implied the town's destruction (a project they have abandoned, according to representatives of the company I spoke with).

Its steepness led the top of the mountain to be historically exploited by small-scale miners. Several attempts to advance large-scale mining have occurred since the 1980s, but they came to only modest fruition in the lower part of the mountain with Mineros Nacionales (a Colombian company recently acquired by the Canadian corporation). The top of the mountain was the site of the town itself, whose nine thousand inhabitants lived alongside the mines. From the mid-1990s, the government and companies used the language of risk to promote the relocation of the town to a lower, flatter lot called El Llano or, to the promoters, New Marmato. This coincided with the first attempts to buy the titles of the upper zone for astronomic prices, which sent the town into spectacles of conspicuous consumption and surreal stories about local and global speculations. In 2006, amid the aggressive push to buy titles, a landslide damaged parts of the town, including the central plaza, the hospital, and the town hall. The company and acolyte political sectors took the landslide as an opportunity to use further risk talk to avoid reconstruction and ultimately render the area uninhabitable in an act of deliberate ruination (cf. Stoler 2008).

In 2009 and 2010, the multinational company closed the recently acquired mines. In 2011, as gold reached its historic price peak (US\$1,880/oz.), destruction, rumor, and exploration in Marmato pushed up the value of Gran Colombia Gold stocks from a few dollars to a staggering US\$881 per share. ${ }^{3}$ The whole town lost employment and housing, and experienced an existential crisis, as it could not continue its way of existence. In this context, the miners reoccupied the mines to extract its gold-rich pockets. Migrants from the entire region soon flocked to work on these deposits now called guachas. Such pockets and the kind of extraction used resulted in a gold rush in which people from all over Colombia arrived in town with dreams of massive wealth. People in Marmato call this new regime guachería. 
It entails a transition to a sociotechnical system characterized by more informal labor and mine occupations, more mechanization, and the division of labor of extraction and processing. It also implies making use of waste and by-products in a way constitutive of the sociotechnical system. Because of the centrality of potentiality, and also because one of the words used for "waste" is sobrantes (excess, surplus), I translate such substances as leftovers.

Guachería allowed former miners and newcomers to set up small and medium-sized informal mills to process the increasing amount of mineral with techniques they adapted from large-scale mills such as cyanidation, which releases the smallest particles of gold from slurry. Gold poured in as processing times shortened and more people could mill their own minerals. Miners experience this period through an affective sense of acceleration and anxiety. Camila, a young migrant from the neighboring department of Antioquia who makes a living from extracting gold from leftovers, would say that "nobody catches gold": gold is everywhere but ultimately impossible to secure. The expression captures a widespread sense of guachería as a regime of both gold democratization and precariousness. It is a time triggered by conflict, but one in which many people find a relatively decent means of living compared to the incomes of peasants and the urban poor. But it is also a time of precarious existence because small-scale miners do not possess titles, and nobody knows how long the town is going to last. At such a conjuncture, every piece of matter brings hope and opportunity. Gases, fumes, smoke, rubble, debris, mud, and sand all become enmeshed in sustaining the town's population and landscape. These substances offer a reserve and an opportunity to maintain a sociotechnical system that redistributes wealth and a life that promises autonomy.

Guachería engendered a questioning of what kind of political entity the town and its population constituted. The company and the regional and national government tried to stop the phenomenon of guachería through legal intimidation, but a number of miners' organizations emerged to counter the eviction. Miners and legal advisers argued that mining titles expired after six months of inactivity. According to them, the company had lost its rights over the mines. ${ }^{4}$ As part of the legal process, some local leaders, self-employed miners, and their lawyers claimed African and Indigenous descent, two populations that have special legal status in Colombia. Thus, some organizations and initiatives have galvanized around concepts such as "mining heritage" and "ancestral culture."

The irony is that political leaders make use of the legal demands of precarious populations in Colombia (in terms of race and ethnicity), even when these prove difficult to apply in Marmato. The political opportunities emerge because 
people can make a living from the mountain. And as I will describe later, their engagement with the materials that render their lives possible profoundly shape their political openings. At the same time, they all try to come to terms with the fact that bureaucrats, large-scale mining companies, and the leaders of other social movements that oppose gold mining deem their lives outdated, impossible, and futureless.

\section{ENGAGEMENTS WITH LEFTOVERS}

Gold is seldom seen as such in Marmato. When the purest version of the metal is finally extracted, it is quickly sold and taken out of town. Yet during the extraction process many opportunities exist to save gold through its leftovers. At every step of the extractive process, too many forms of labor to capture in a short essay take place. In the remainder of the article, I will therefore concentrate on those that involve a mutual laboring between geological substances and humans. Later, I reflect on the kind of life and future such an engagement creates.

\section{Gases and Smoke}

Mineral reactions underground, dynamite, and gunpowder create toxic gases. In the final phases of gold processing there are acids that release fumes. Miners have a difficult, but potentially fruitful relationship with both. Gases in mines and fumes in mills seem to constitute simple, if dangerous, by-products, but at different levels, miners, through their engagements, turn the danger into socially productive matter.

Gases in mines index both the right and the wrong socialities and materialities involved in the extraction of gold. After the rock is broken down, ethereal substances are the first matter miners deal with in their search for gold, as, in the mines, it is gases that define the possibility or impossibility of inhabiting the tunnels. Antonio Rotavinski is one of the few miners who did not sell his mine when "the Canadians" arrived in 2006. Shirtless, he explained to me the intricacies of operating a mine in the times of guachería. In the absence of legal delimitation, mine tunnels constantly meet. Workers come and leave with ease, and he has several sections operated by independent groups of miners who pay him a fixed monthly fee for usage. The most difficult part, however, is avoiding the constant danger of suddenly falling to the bottom of the mine. The unplanned work in the mines has made miners working toward the top of the mountain go in all directions, leading to complex communicative tools in the mine shafts, which include shouting and hitting the rock. All these require a heightened attentiveness 
to voices and explosions in other mines near the front (the deepest and farthest section) of the tunnel. Small-scale miners have also descended into lower levels that belong to the mine of the Mineros Nacionales title. But Mineros Nacionales, the branch of the multinational company operating in the mountain, have gone too high as well. Apparently, the latter did not happen by accident: "The multinational is trying to poison us," said Antonio. Gases from extraction were moving up to the higher part of the mines, turning those tunnels into uninhabitable chimneys. Parts of 5200, a formerly very productive mine, thus became a trap of poisonous fumes, in which temperatures could reach $50^{\circ} \mathrm{C}$.

As legal disputes continue, the everyday strife of the small-scale miners centers on keeping the mines habitable and productive. The ability to breathe in the mines constitutes one of the central survival issues for workers. Delivering the service of "air" through pumps and pipes is a lucrative business, and most often a way of getting into the business. The relationship with poisonous gases involves idioms of caring practices among men. As I was chatting with and helping Juan Carlos, a fifty-year-old guachero (guachería worker), load sacks of mineral onto trucks, two younger men approached to listen to us. One was placing dynamite, planning to ignite it to reenter the mine. The other had just emerged from the shaft. As Juan Carlos and I talked about the risks of gases and how he perceived the toxic fumes by the kind of itch he felt in his eyes, the younger guacheros took the occasion to brag about their bravado and success. Juan Carlos stopped them, uttering a warning in rhyme: "Don't be confiados [trusting, but also naive] and porfiados [stubborn]; listen to others - mines aren't dangerous until they are." The act of caring among men entails teaching and learning to wait, involving affects such as patience and prudence. The aftermath of explosions is a tense time for guacheros. Eager to see the uncovered vein they are trying to follow and worried that someone might steal their ore, miners must get into the tunnels as soon as possible.

Life in the shaft involves the constant rubbing of bodies against each other, as darkness is interrupted by beams of light emanating from the headlamps. The sound of hammers and pikes echoes through the tunnels, indicating where other workers are. At midday, miners sit by the entrance with their lunches packed in plastic boxes or plant leaves. The mines are an intimate space. Mario, another mine laborer, told me that some mines were so hot that miners had to work in trunks, pouring water over their bodies to cool down. Charged with ammonia, gases coming from the mines smell like urine. Learning to survive in a masculine environment and sharing the air is one of the central elements miners mention about working in the tunnels. "Watch out, the mine is spicy [picante]!" is a common 


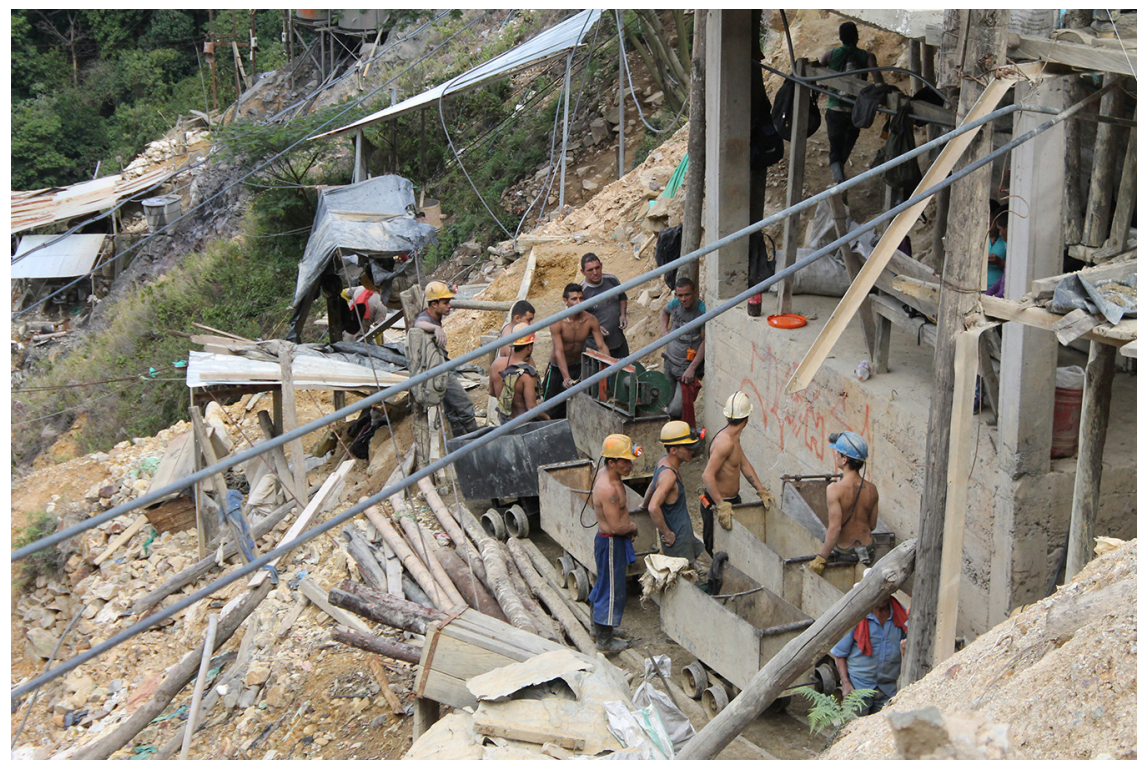

Figure 2. Guacheros in the mouth of a tunnel. Photo by Pablo Jaramillo.

way of warning coworkers about the presence of odorless gases that are felt as a burning sensation in the eyes. Workers in the shafts have a sense of pride about the mines' and their own smells. Leidy, a woman who worked as an environmental technician for a company, would laugh mentioning that miners hated it when she went to the mines wearing perfume. The gases are dangerous by-products, but also indices of shared, deep, buried lives.

According to Alex, the municipal Authority on Mining Issues (a joint office of the police and the mayor's office that has auditing and conflict-resolution functions) stated that one of the Canadian company's main issues with the miners working further up the mountain was a different type of effluvium: marijuana smoke. Clouds of smoke get into the upper galleries of the corporation's mines, which treats this as a nuisance. Alex, who has been called to mediate in the conflict, says that "the lads like to smoke chirusa [weed]; for them, it is normal to get high in the mines." Then we laughed about the twist in the political clash caused by smoke, and the implications of marijuana fumes on conviviality, mellowness, and mines as living spaces.

The minerals themselves produce deadly gases, making some mines chronically dangerous. But the fumes of recent dynamite explosions are a more common cause of death among young, impatient miners who are too eager to get their hands on the mineral and the gold contained in it. To sustain such an intricate ex- 
istence with others involves a sense of shared means and ends. Waiting to reenter a mine after an explosion is of vital importance in this regard. Cristina, the woman in charge of the statistics at Marmato hospital, explained the point very clearly with an example: "Last month two youths died in a mine; they had done well, but they went crazy with the money, and when they blew the dynamite the last time, they were too eager to take out the mineral and entered the mine at night. They were found there, dead, engasados [poisoned by gas]." Gas indexes the potential of extraction and defines, in practice, a time to extract and a time to wait.

The possibility of becoming engasado is one of the main complaints miners raise against Mineros Nacionales, the company operating in the mountain's lower zone. Additionally, the multinational company and governmental programs of mining formalization - that demand operating on mines with official titles, paying taxes, and registration of workers in the social security system-have advanced an aggressive campaign to hire the miners who occupied the disputed mines as guacheros for little more than a monthly minimum salary (US\$250, compared to a guachero's monthly average of US\$600). The miners disliked many things about working for the company: having a boss, earning less, and the rare opportunities for having a lucky strike. One of those employed by the multinational company as a hired hand was Rubén. When I accompanied him to his 5 p.m. to 1 a.m. shift in the mine, he complained that for the companies, "there was no Easter, no Christmas, there aren't weekends either." The large mine of the multinational operated in a time parallel to the social time of the residents of Marmato.

The image of people engasada in Mineros Nacionales mines would arise in conversations again and again, and it captures the mixture of carelessness and greed that miners associate with gas poisoning. Small-scale miners attribute the number of engasados in Mineros Nacionales to a pace of production hostile to miners' lives. Tunnel fumes thus point to a feature present in all treatment of waste and leftovers, that is, to the possiblity of turning fear into a productive attitude toward life and future. Rubén, who was born in Marmato and worked in the multinational's mine only because his divorce obliged him to have a formal job, linked the pace of extraction to the premature ending of Marmato. He told me this while explaining his job in the mine to me. He is an entubador, a pipefitter, in charge of fixing and installing the infrastructure for ventilation in the tunnels. Without clean air getting in and toxic air being expelled, it would be impossible for the mine to operate in three shifts, 24/7. Moreover, the three shifts figured prominently in Rubén's view that the large-scale mine had the ability to multiply time: "When the first twenty-year concession to operate La Palma [the main mine now 
operated by the multinational] was granted, nobody realized that this amounted to sixty years, if you operate three eight-hour shifts."

Volatile substances point to the tension between matter and what it might contain, a kind of reserve or even actual resource (cf. Richardson and Weszkalnys 2014). Gas is a substance constantly released in mills as part of the final cleaning process of gold. Even after washing the fine-grained sands, a mixture of lead and copper remains attached to the gold. Millers add nitric acid to the final, gold-rich mud to burn away these elements. The process leads to the release of an orange smoke, dreaded by those working in the mills because it "poisons the blood" and makes men sexually impotent. Yet the fumes' toxicity also constitutes a source of opportunities. For Johan, a prominent leader in the demonstrations surrounding mine closures, fumes are not so much a poison but a leftover. He therefore decided to set up Terranova, his own "sustainable mill" that "focuses on the maximum retrieval of gold." Johan is most proud of a system of chimneys and filters he developed in which he captures gold from the smoke and fumes that result from the cleaning process. He rinses the filters, sponges the pipes, and then washes the resulting slurry to retrieve a few more grams of gold. Thus, gases, fumes, and smoke again indicate a sign of the always present potential for life and death in mineral substances.

Miners can transform their own lives and, ultimately, Marmato as they engage in a relationship with the gases. Gas is a substance created by mineral and human reactions, one that also shows the potentiality and promise of gold. But it also signals dangers, fears, an accelerated pace of extraction, and a productive affective relationship with risky shafts. Gases are the breathable substance of miners' lives in the underground, and they shape overtly masculine relationships built around the extraction of a mineral from tunnels.

\section{Rubble}

Rubble constitutes rocks without pyrite that are extracted from the mines. In the shafts, experienced miners define where to locate dynamite charges in the front of a mine. Younger people in the team ignite the explosives. This has become a very dangerous task since the national government restricted the circulation of safe, legal explosives as part of antiterrorist measures in the country. The prohibition began to be enforced precisely at the time the miners retook the mines in the conflict with the Canadian company, a coincidence widely interpreted in Marmato as retaliation and the beginning of a new episode in a long-standing process of criminalization. 
Taking the rubble outside the shafts constitutes one of the most labor-intensive parts of the relatively manual activities practiced at the top of the mountain. People who take the rubble outside the mines use a manual winch and pushcarts. The activity by far requires the most muscle labor, and although workers alternate tasks, the more novice and youngest of the lot tend to perform this job. Rubble management therefore constitutes the entry-level job in the trade. Rubble is thrown outside the mine, near the entrance, and the rocks roll down and rest in critical equilibrium, coating the mountain and rendering the soil sterile to plants. The rocks might later fall from a few to dozens of meters down the hills. Quarrels sometimes emerge around discharges of materiales (materials) that another miner deems too harmful or a nuisance. Small to medium-sized rocks lie on the steep hill_-potentially dangerous, but also a source of livelihood.

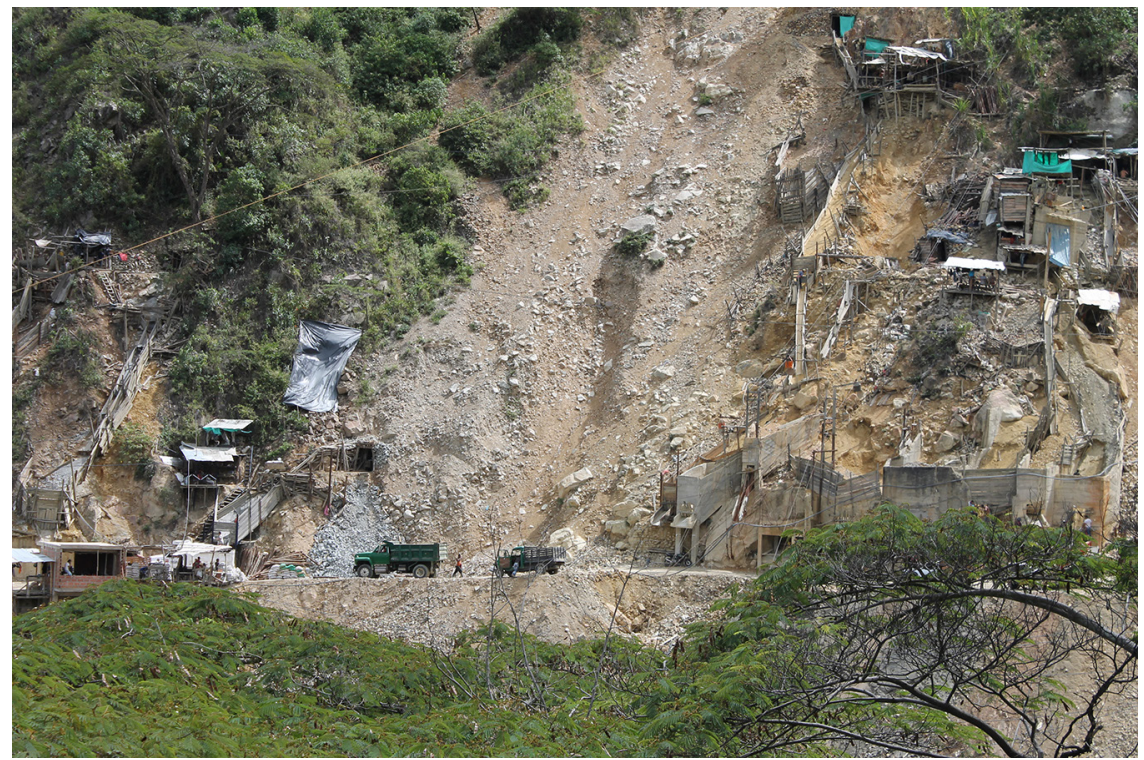

Figure 3. Mining debris on the slope. Photo by Pablo Jaramillo.

Beyond a mere risk, rolling stones offer an idiom with a special affective capacity for the Marmato residents to face danger and change. Stories about rolling stones can be heard everywhere in town. My comments that the place was dangerous because there was too much debris coming out of the tunnels often triggered such tales. The conversation would usually end with a remark about the outsider's inability to deal with rolling stones. Eulises, an active local leader, mineral trader, and amateur lawyer, would explain, "When a rock is rolling down a hill, you do 
not run. As it goes down, bumping from one place to the other, you turn and face it. Then you wait until the rock is close enough and avoid it in its last bounce. You never run, or the rock will chase you!" Leftovers of tunnels provide miners with an affective relationship with the mountain.

Workers and residents repeat tales of this kind relentlessly. Storytellers list survivors and victims of rocks, as well as the situations surrounding such events. The stories have meaning beyond their cautionary nature. Outsiders, Eulises says, consider Marmato a disorderly pile of rubble only because they fail to inhabit its surroundings and move around; strangers cannot even walk. Narrating and dwelling, senses and affect within a landscape of rubble are inextricably linked.

Rubble also features prominently in talk about fate approaching a person. Thus, stories of rolling stones and their victims also take alternative forms in which people appear as marcado (marked) for death. The rocks chase people because something had to happen to them, and storytellers invoke proverbs and tropes of fatefulness and predestination. A youth of seventeen had died in a mine just a few days before I spoke to Eulises. The event captured the imagination of all interlocutors during those days, not because dying in shafts was rare, but because a mineral block had fallen from the ceiling at the entrance of the mine. What struck people was that the young man did not even work as a miner. He was "marked," according to Eulises and the women in the hospital who registered his death. On hearing these stories in a mill, my partner said that in Marmato, people seemed more open to the idea of dying. The people around emphatically rejected that interpretation: "We care about death as much as you do, but death is always there." The relationship with rubble demonstrates that life and death are always readily contained in the mineral. In their everyday dealings with leftovers, people experience in practical ways otherwise abstract notions of future contained in concepts such as destino (destiny). This forms part of a widely shared view that any activity dealing with gold always already entails a problematic potentiality, a maldición (curse). Infamously wealthy entrepreneurs are cursed because they are destined to return to poverty. Such ideas have reverberations beyond the lives of individuals. Many accounts, for instance, see Marmato condemned to an always recurring cycle of slavery - today's conflict and crisis only yet another instance of an event that already happened during the Spanish colonial period, the hacienda regime, and the concessions of the mines to London companies in the aftermath of Colombia's independence. Yet the ambiguous potentiality of gold can also be countered by literally standing up to rolling boulders. 
Out of place, rubble and rocks are potentially dangerous, but they also provide a possible source of livelihood. Like the gases and fumes produced in the mines, they are always by-products engaged productively. The people of Marmato widely regard the town as a rebuscadero, a scrambling place, a town where people come to find a living and become enmeshed in intricate networks of labor, kinship, and dwelling. Rebuscadero not only constitutes a sociological and spatial category. It is, most explicitly, a strategy for survival people call rebusque, which involves searching for hidden opportunities in the scattered rocks. People who practice such a strategy call themselves rebuscadores. During the extraction process, fragments of pyrite end up in the debris thrown out of the mines. Minerals taken in sacks, cable cars, buckets, and canalized in silos also fall and end up in the rubble. The townspeople most marginalized survive partially or entirely by recovering fallen pieces of mineral. Rocks picked around mines are not sold or bought, they are rebuscadas — sought and found with considerable effort and cunning. Miners around the tunnel entries do not claim any property over the mineral in the rubble, and no authorization is required by, requested from, or granted to rock pickers. However, mine owners and rebuscadores often told me that this order of things stood as an expression of the generosity and solidarity characteristic of Marmato, distributed in the form of rubble and other materials.

Rubble implies a sense of survival but also of the temporality of life. The relationship between stones rolling down the hill and making a living out of fallen rocks conceives a life in which events approach persons. This is closely tied to the notion of the Catholic devenir in which it is the future that approaches the person, not the other way around, such as in the modern notion of the future as a space of possibilities to be filled. Thus, the life created through engagement with rubble comes with temporal affect and a sense of temporal orientation that allow miners to build meaningful existences, even in the context of imminent and violent eviction. In the end, the mineral goes to the mills and is transformed into massive amounts of sand and mud.

\section{Sand and Mud}

Miners take mineral out of mines to be processed in mills. Small-scale mills grind rocks with manganese or iron balls tumbling in a mechanical drum. The resulting sand goes through a Wilfley table, the output is washed in pans, and finally cleaned with nitric acid. Remnants of the process still contain gold in important quantities. Mill workers pass coarser sand through the drums again. It is toward the third or fourth grinding that people call the tailings conchos and they become 
a valuable leftover that can be saved to cover future expenses or sold to people willing to grind them again and take a piece of the remaining gold.

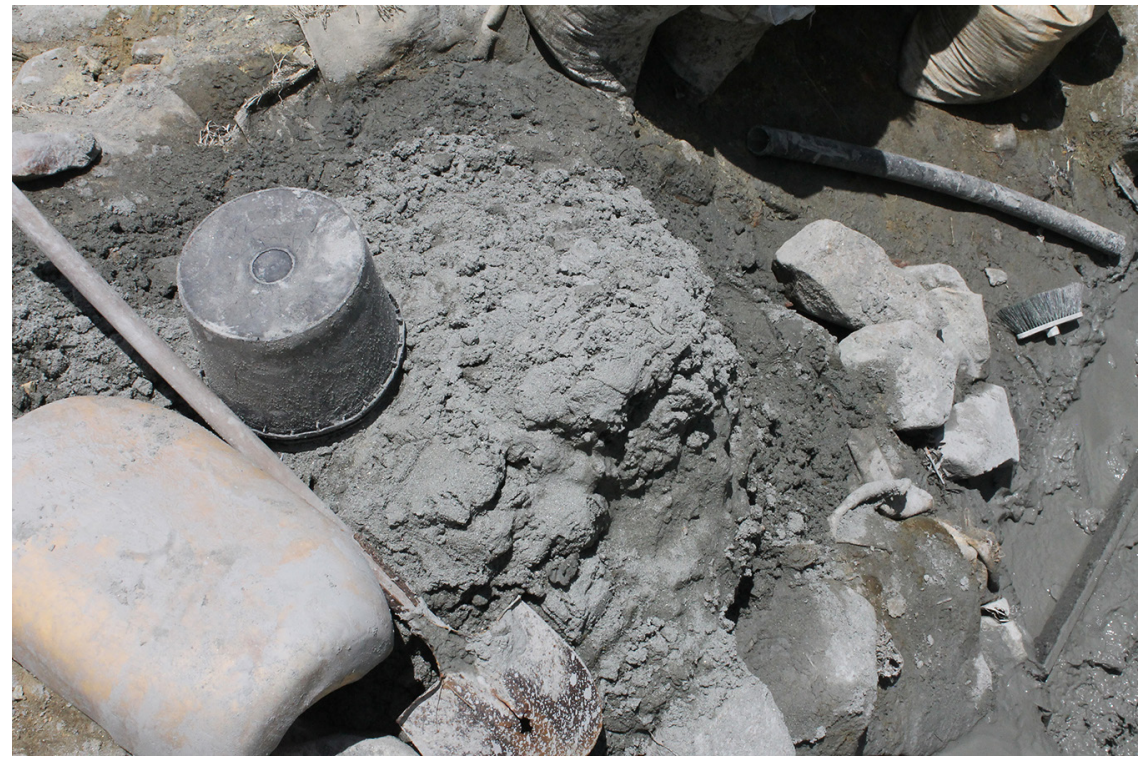

Figure 4. A pile of conchos. Photo by Pablo Jaramillo.

The circulation of conchos involves most people in town. First, there are the gold cortadores, "cutters," people who extract gold from sands in wooden pans (bateas). They are experienced people who stopped working in the shafts (they consider themselves too experienced for such a burdensome task). The places where cutters work (cortaderos) are hectic nodes of speculation about the trading of minerals, gold, and leftovers. Miners and non-miners, men and women, and people of all ages and origins buy buckets of sand at cortaderos.

Trading in conchos offers a way of getting into the business of extracting gold without going into the tunnels. Thus, women and newcomers are prominent buyers, while male miners most often function as prominent sellers. Until a recent change in the Colombian Labor Code, women were forbidden to take jobs in underground areas, making conchos a favored alternative for them. Because it requires less strength or skill, newcomers would get involved in the cumbersome materialities, times, and circulation of gold via conchos and eventually develop the knowledge, sensitivity, and relationships enabling them to perform other more lucrative tasks. These might involve deploying more relationships to extract and process greater quantities of mineral and, therefore, extract more gold, but they also create gas, rubble, and sand in the process. 
It is the potentiality and reproduction of substances such as sand and mud that guarantee the permanence of small-scale miners in the mountain. Conchos oxidize with exposure to air, releasing more gold, a well-known process that has miners insist that "gold reproduces" in the piles of sand. Such views on the generativity of gold form part of broader notions of the metal as alive and cunning. The mineral hides itself in the mines. Workers say that greed and an overly strong desire for wealth affect gold, producing rejection. In turn, the desire for gold based on sharing or wasting wealth conspicuously attracts gold - it comes to people in a physical and temporal sense. In a similar way, finding gold in conchos is a matter of unlocking the metals still contained in the minerals, and time is crucial to let this happen. It is in the times when mines flood or shops close that miners sell or grind conchos to earn money. They can also sell the conchos outright after grinding the material, but transactions demand the buyer be part of a network of miners. Miners often hand out conchos as gifts or alms, exhibiting another way of introducing time in conchos through delays in material circulation. In the case of alms, the recipient might end up with either a small or a huge quantity of gold. "Once a woman came begging for food, and the owner of that mine gave her a bucket of sand instead," explained Mario, the same miner who insisted on Marmato's alternative futures. "The woman got an incredible amount of gold from it and couldn't stop crying." The surprise in conchos, unpredictable gifts, reinforces the idea that gold will appear to the right people at the right time. As with rolling stones, this kind of circulation creates a sense of forthcoming among those involved, a world of preperceived potentialities, as opposed to an abstract future with endless possibilities (cf. Bourdieu 1963).

The circulation of conchos reproduces gold, social relations, and certain ideas about the future. It is impossible for two buckets of conchos to be commensurate, which is why it is key to know the mine from where the mineral originated, the grade of that mine, the kind of gold it produces, and, most important, the seller. A naive buyer might find themselves deceived with fabricated conchos, that is, regular soil with an addition of gold dust, ultimately "sterile" after the added gold has been extracted. In this way, saving, selling, and grinding conchos constitutes a way of storing potential wealth.

Other leftovers like mineral found in the debris of tunnels or in the surroundings of mines are available to everyone who wants to collect them. This makes conchos a leftover indexing the redistribution of wealth in Marmato. However, while tailings represent a widespread source of wealth, these remains can become dangerous at many levels. Poison (veneno) is a word used for substances 


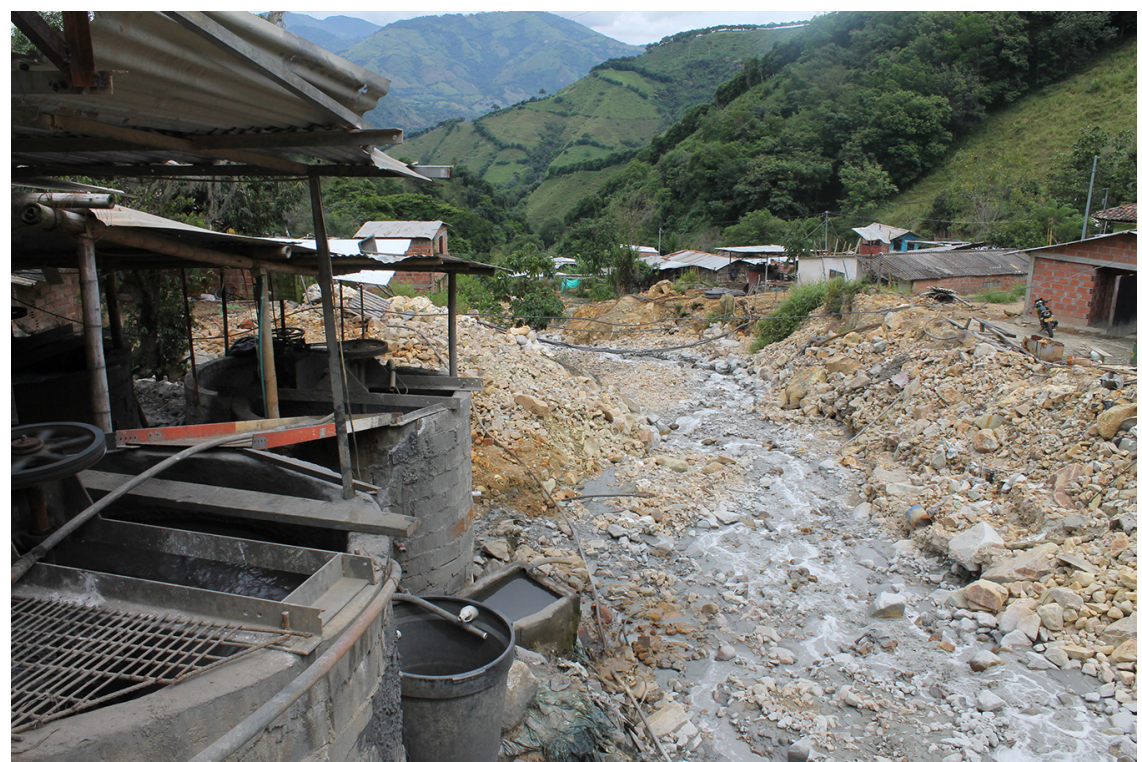

Figure 5. Cyanide leaching tanks pouring tailings into creeks. Photo by Pablo Jaramillo.

like cyanide, but also to refer to fabricated conchos. Therefore, a certain kind of tailing involves the risk of dangerous relationships. For this reason, learning to deal with conchos involves lessons about moral motivations and the nature of Marmato's sociality.

At every step of the milling process, sand falls outside the tables, canals, and sacks. This mud is the mill owners' payment. They put the debris in piles and every two weeks pour it into tanks with cyanide in a process called cyanidation or leaching. In another instance in which the center and the margins of capitalist accumulation connect, medium-sized companies introduced leaching in the late 1930s, but only in the 1980s did it become widespread as part of the government's efforts to increase yield. Cyanide precipitates gold in the smallest pyrite structures and leads to, literally, "liquid gold." Nearly every mill constructed after guachería has a leaching tank. This has effectively created a local entrepreneurial class mostly occupied by newcomers who soon became moneylenders. However, for small-scale miners occupying the mines, this development made for only a minor problem, since the newcomers integrated into local networks of kinship and mining.

Cyanide is what allows mill owners to make a living, but it is also a deadly substance. Miners associate cyanide with suicides and barren landscapes. For instance, creeks are the working area for miners that wash mineral in sluice boxes. They extract gold from slurry poured by mills, but they also complain that the 
process of leaching "burns" the gold. Leaching thus affords yet another occasion in which leftovers entail both the democratization of gold and the marginalization of people in town. Again: hope and despair.

The use of leaching in small-scale mills attracted other dangerous businesses, such as the importation of suspicious tailings. Small-scale mining in Marmato does not use mercury, but mill workers began discovering mercury in leaching tanks, indicating obscure relationships. Nearly a hundred kilometers north of Marmato lies Buriticá, another mining town under the control of paramilitary mobs and another Canadian mining corporation. In Buriticá, the use of mercury to amalgamate gold is widespread in illicit extraction because it is cheap and adapts well to the alluvial mining practiced there. Mill owners in Marmato started to import polluted sands from Buriticá to conduct leaching and extract the remaining gold.

Processing the sands from Buriticá proved extremely profitable for mill owners in Marmato. For Johan, who extracts gold from fumes, such windfall gains were a risky bonanza. To him, very few people wanted to talk about the business, because it was illegal, involved invisible relationships with paramilitary gangs, and, most important, implied dealing with a dreaded substance. The presence of mercury also implied more potential auditing of gold production in town, thus eventually fostering the further criminalization of small-scale mining. Thomas Robertson and Trisia Farelly (2018) describe the way mercury-elimination programs in Buriticá have implied deep entanglements between small- and large-scale mining, leading to regulation, new labor arrangements, and the loss of autonomy for smallscale miners.

Because it makes for a profitable and widespread business, the consumption, production, and circulation of mud and sand are ultimately responsible for the financial sustainability of small-scale miners. But the potentiality to sustain this life in the margins of capitalism also contains the danger of poisonous relations and substances. In this context, dealing with muds also literally means dealing with the poison coming out of violence elsewhere. Small-scale miners who intend to resist violent and exploitative processes also react by countering the dangerous potentials in leftovers. Cleaning the latter offers a way of navigating the violence and criminalization that leftovers might carry.

\section{CONCLUSION}

Luciana Massaro and Marjo de Theije (2018) have shown that small-scale miners in Brazil have innovated cleaner production methods without relying on the solutions offered by large-scale mining. Rather than being present-oriented, 
small-scale Brazilian miners base their innovation on a clear sense of foresight, agility, and development. In a similar vein, I have found that these other temporal affects rely on small-scale miners' engagement with leftovers to expand opportunities in time and space. I therefore show the capacity of small-scale miners to develop future-making relationships and alternative forms of social duration and perdurance that go beyond mainstream notions of economic development and growth. Engagements with leftovers involve human and nonhuman collaboration to unlock and deal with ambiguous potentialities - in my ethnographic case, the potentialities of geological substances, waste, poison, and many others. The mutual engagement proves crucial for the survival of people affected by the contradictions of financial and extractive capitalism and local violence.

Beyond a focus on the way capitalism instrumentalizes nonhumans, I demonstrated how local communities engage in practices of future-making in the face of the imminent annihilation of their ways of life. The first consequence of the work of and around leftovers is the extension of the present in which small-scale miners' lives perdure. The first strategy to stretch the present is waiting as an agentive act that expands the duration of Marmato's mines. For instance, the timing to reenter a tunnel because of poisonous gases combines a sense of the pace of extraction, a moral vision, and affects such as calm, hope, and fear. The second consequence is a redistribution of gains and losses for most of the population and for future generations. While estimating the amount of gold he had obtained from a lot of minerals, a miner would comment that in Marmato gold is constant. "It is an illusion that their mines are exhausting; the point is that there are always miners that are 'seeing' the gold and others that are in the process of obtaining it." The constancy of gold means that no seasonal variations in production can mark the passage of time and a sense of enduring life can be achieved.

Contrary to the widespread notion in governmental offices that small-scale miners do not have a sense of future, I have demonstrated that leftovers entail a collaboration between human and nonhumans that creates an expanded present and value through differentially activated materials. Inhabiting such an expanded present constitutes a way of creating a forthcoming (cf. Bourdieu 1963, 61). I understand this temporality as opposed to financial and speculative capitalism, but nevertheless as part of the heterogeneity of times present in current global economic regimes.

Leftovers turn capitalist pause and temporal dispossession (as in the decision of the mining company to close the mines) into an agentive livelihood practice for small-scale miners. The interplay between humans and nonhumans effectively 
leads to waiting moments. It is in these wait times that gains are attained, and survival is possible. Therefore, paying attention to human and nonhuman engagements in the experience of marginalization offers a way to deal with and resist the kind of temporalities and durations imposed by multinational corporations and neoliberal governments. Economies of leftovers are a situated response practiced in Marmato and elsewhere to the unsustainable lives that come with policy programs involving notions such as progress, development, and "a better future." Collaboration with leftovers is a practice of building mutuality with, within, and around the mountain that sustains Marmato. The political imagination in marginalized areas thus offers a basic template of resilience and reconstruction, characterized by intensities located in the relationship between humans, minerals, gases, mud, and mining technologies.

\section{ABSTRACT}

The Colombian government and large-scale mining companies accuse small-scale gold miners of lacking a sense of the future, thereby harming the future of Colombia. In this article, I argue that marginalized people who extract gold with small-scale techniques create an alternative sense of future by engaging with the leftovers of their gold mining practices. This article is based on ethnographic fieldwork with people who struggle to make a living in the wake of large-scale mining interventions in the town of Marmato. Small-scale mining constantly creates simple by-products-gases, rubble, and mud - that look like waste. Small-scale miners engage with such substances as a way to make sense of their lives and the future. Making the relationships between humans and geological substances, waste and technology visible elucidates alternative forms of life that "get in the way" of a multinational mining company, the national government, local mafias, and financial markets hungry for gold in times of crisis. By analyzing people's engagement with leftovers, I offer an understanding of resilience and survival in the margins of capitalist cycles of violence. [leftovers; affect; future; mineral resources; gold; mining conflicts; work; nonhumans]

\section{RESUMEN}

El gobierno de Colombia y las compañías mineras a gran escala ven la minería a pequeña escala como una práctica sin futuro y dañina para el país. En este artículo argumento que las personas marginalizadas que extraen oro a pequeña escala crean sentidos de futuro alternativos al entrar en relación con las sobras de sus propias prácticas mineras. El artículo está basado en trabajo de campo etnográfico en el pueblo de Marmato, con personas que luchan por sobrevivir ante la inminencia de la ejecución de un proyecto de minería a gran escala en la montaña donde se localiza el pueblo. La minería a pequeña escala crea subproductos de manera permanentecolas, sobrantes y restos - que parecen basura. No obstante, los mineros a pequeña 
escala se involucran con estas sustancias como una forma de hacer sentido sobre sus propias vidas y futuros. Hacer visible la relación entre humanos y sustancias geológicas, desechos y tecnología hace posible apreciar formas alternativas de vida que "se ponen en el camino" de una multinacional minera, el gobierno nacional, mafias locales y los mercados financieros que buscan oro en tiempos de crisis. Al analizar la relación de las personas con gases, escombros, rocas, y barro, aporto una posibilidad de entender la resiliencia y subsistencia en los márgenes del capitalismo y sus ciclos de violencia. [sobras; afecto; future; recursos minerales; oro; conflictos mineros; trabajo; no-humanos]

\section{NOTES}

Acknowledgments The writing of this article was possible thanks to a Newton Fund Researchers Link travel grant (British Council) by the UK Department for Business, Energy and Industrial Strategy (BEIS). Special thanks to Giselle Figueroa, Gisa Weszkalnys, Austin Zeiderman, Laura Bear, Katy Gardner, and Rodrigo Charaffedine Bulamah for their valuable support and suggestions at different stages of this article. I am also grateful to the anonymous reviewers and members of the Cultural Anthropology editorial collective, particularly to Brad Weiss, for their constructive engagement with my ideas.

1. Including the 2002 Regulatory Decree for the Legalisation of De Facto Mining (Decree 2390 / regulatory Decree of Article 165 of the Mining Code), the National Mining Development Plan, the 20101382 Law, which reformed the 2001 mining code, the 2012 Decree 2235, which penalized illegal mining, the 2013 Decree 933 on formalization, and the Decree 935 on mining titles (Echavarria 2014).

2. Data from gold.org (see Goldhub 2019).

3. Data from listings on the Toronto Stock Exchange. See https://web.tmxmoney.com/ quote.php?locale=en\&qm_symbol=GCM (accessed September 22, 2019).

4. The Colombian Constitutional Court first backed the local miners' argument (T-438 of 2015) and then reverted the ruling (A-583 of 2015). In February 2017, the Constitutional Court (SU-133 of 2017) finally supported the arguments of the small-scale miners, saying that a prior informed consultation should have taken place before the acquisition of the titles and ordering the mining company to institute one.

\section{REFERENCES}

Bear, Laura

2014 “Doubt, Conflict, Mediation: The Anthropology of Modern Time." Journal of the Royal Anthropological Institute 20, supp. 1: 3-30. https://doi.org/10.1111/14679655.12091.

Beckett, Caitlynn, and Arn Keeling

2019 "Rethinking Remediation: Mine Reclamation, Environmental Justice, and Relations of Care." Local Environment 24, no. 3: 216-30. https://doi.org/10.1080/1 3549839.2018.1557127.

Benson, Peter, and Stuart Kirsch

2010 "Capitalism and the Politics of Resignation." Current Anthropology 51, no. 4: 459Besky, Sarah 86. https://doi.org/10.1086/653091.

2014 "The Labor of Terroir and the Terroir of Labor: Geographical Indication and Darjeeling Tea Plantations." Agriculture and Human Values 31, no. 1: 83-96. http:// doi.org/10.1007/s10460-013-9452-8. 
Blanco, Gustavo, Alberto Arce, and Eleanor Fisher

2015 "Becoming a Region, Becoming Global, Becoming Imperceptible: Territorialising Salmon in Chilean Patagonia.” Journal of Rural Studies 42: 179-90. https://doi.

Bourdieu, Pierre org/10.1016/j.jrurstud.2015.10.007.

1963 "The Attitude of the Algerian Peasant towards Time." In Mediterranean Countrymen: Essays in the Social Anthropology of the Mediterranean, edited by Julian Pitt-Rivers, 55-72. Paris: Mouton.

Bury, Jeffrey, and Anthony Bebbington

2013 "New Geographies of Extractive Industries in Latin America." In Subterranean Struggles: New Dynamics of Mining, Oil, and Gas in Latin America, edited by Anthony Bebbington and Jeffrey Bury, 27-66. Austin: University of Texas Press.

D’Angelo, Lorenzo, and Robert J. Pijpers

2018 "Mining Temporalities: An Overview." Extractive Industries and Society 5, no. 2: 215-22. https://doi.org/10.1016/j.exis.2018.02.005.

Echavarria, Cristina

2014 “What Is Legal?' Formalising Artisanal and Small-Scale Mining in Colombia." London: International Institute for Environment and Development.

Ferry, Elizabeth Emma, and Mandana E. Limbert, eds.

2008 Timely Assets: The Politics of Resources and Their Temporalities. Santa Fe, N.Mex.: School for Advanced Research Press.

Gärtner, Álvaro

2005 Los místeres de las minas. Manizales: Editorial Universidad de Caldas.

Gilbert, Karen Wendy

2007 "Slowness: Notes toward an Economy of Différancial Rates of Being." In The Affective Turn: Theorizing Social Theory, edited by Patricia Ticineto Clough with Jean Halley, 77-105. Durham, N.C.: Duke University Press.

Goldhub

2019 “Gold Prices." Goldhub, December 9. Accessed September 22, 2019. https:// www.gold.org/goldhub/data/gold-prices.

González Colonia, Carlos Julio

2017 Brujería, minería tradicional y capitalismo transnacional en los Andes Colombianos: El caso del pueblo minero de Marmato. Bogotá: Instituto Colombiano de Antropologia e Historia.

Gordillo, Gastón R.

2014 Rubble: The Afterlife of Destruction. Durham, N.C.: Duke University Press.

Halvaksz, Jamon Alex, II

2008 "Whose Closure? Appearances, Temporality, and Mineral Extraction in Papua New Guinea." Journal of the Royal Anthropological Institute 14, no. 1: 21-37. https://

High, Mette M. doi.org/10.1111/j.1467-9655.2007.00476.x.

2017 Fear and Fortune: Spirit Worlds and Emerging Economies in the Mongolian Gold Rush.

Kneas, David Ithaca: Cornell University Press.

2016 "Subsoil Abundance and Surface Absence: A Junior Mining Company and Its Performance of Prognosis in Northwestern Ecuador." Journal of the Royal Anthropological Institute 22, supp. 1: 67-86. https://doi.org/10.1111/14679655.12394.

Labban, Mazen

2014 "Deterritorializing Extraction: Bioaccumulation and the Planetary Mine." Annals of the Association of American Geographers 104, no. 3: 560-76. https://doi.org/10.10 80/00045608.2014.892360. 
Lanzano, Cristiano

2018 "Gold Digging and the Politics of Time: Changing Timescapes of Artisanal Mining in West Africa." Extractive Industries and Society 5, no. 2: 253-59. https://doi. Luning, Sabine org/10.1016/j.exis.2018.02.006.

2018 "Mining Temporalities: Future Perspectives." Extractive Industries and Society 5, no. 2: 281-86. https://doi.org/10.1016/j.exis.2018.03.009.

Massaro, Luciana, and Marjo de Theije

2018 "Understanding Small-Scale Gold Mining Practices: An Anthropological Study on Technological Innovation in the Vale do Rio Peixoto (Mato Grosso, Brazil).” Journal Millar, Kathleen M. of Cleaner Production 204: 618-35. https://doi.org/10.1016/j.jclepro.2018.08.153.

2014 “The Precarious Present: Wageless Labor and Disrupted Life in Rio de Janeiro, Brazil." Cultural Anthropology 29, no. 1: 32-53. https://doi.org/10.14506/ca29.1.04.

Peluso, Nancy Lee

2018 "Entangled Territories in Small-Scale Gold Mining Frontiers: Labor Practices, Property, and Secrets in Indonesian Gold Country." World Development 101: 400416. https://doi.org/10.1016/j.worlddev.2016.11.003.

Richard, Analiese, and Daromir Rudnyckyj

2009 "Economies of Affect." Journal of the Royal Anthropological Institute 15, no. 1: 57-77. https://doi.org/10.1111/j.1467-9655.2008.01530.x.

Richardson, Tanya, and Gisa Weszkalnys

2014 "Introduction: Resource Materialities." Anthropological Quarterly 87, no. 1: 5-30. https://doi.org/10.1353/anq.2014.0007.

Robertson, Thomas, and Trisia Farrelly

2018 "An Ethnography of Entanglements: Mercury's Presence and Absence in Artisanal and Small-Scale Gold Mining in Antioquia, Colombia." Sites 15, no. 1: 38-69. http://dx.doi.org/10.11157/sites-id349.

Salman, Ton, and Marjo de Theije

2017 "Analysing Conflicts around Small-Scale Gold Mining in the Amazon: The Contribution of a Multi-Temporal Model." Extractive Industries and Society 4, no. 3: 586-94. https://doi.org/10.1016/j.exis.2017.03.007.

Smith, James H.

2011 “Tantalus in the Digital Age: Coltan Ore, Temporal Dispossession, and 'Movement' in the Eastern Democratic Republic of the Congo." American Ethnologist 38, no. 1:

Stoler, Ann Laura 17-35. https://doi.org/10.1111/j.1548-1425.2010.01289.x.

2008 "Imperial Debris: Reflections on Ruins and Ruination.” Cultural Anthropology 23, no. 2: 191-219. https://doi.org/10.1111/j.1548-1360.2008.00007.x.

Tsing, Anna Lowenhaupt

2015 The Mushroom at the End of the World: On the Possibility of Life in Capitalist Ruins. Princeton, N.J.: Princeton University Press.

Ureta, Sebastián

2016 "Caring for Waste: Handling Tailings in a Chilean Copper Mine." Environment and

Weszkalnys, Gisa Planning A 48, no. 8: 1532-48. https://doi.org/10.1177\%2F0308518X16645103.

2015 “Geology, Potentiality, Speculation: On the Indeterminacy of First Oil." Cultural Anthropology 30, no. 4: 611-39. https://doi.org/10.14506/ca30.4.08.

2016 "A Doubtful Hope: Resource Affect in a Future Oil Economy." Journal of the Royal Anthropological Institute 22, supp. 1: 127-46. https://doi.org/10.1111/14679655.12397. 